\title{
Viagem às terras que inspiraram a obra "Morte e Vida Severina"
}

\author{
LEONARDO SAKAMOTO
}

$\mathrm{R}$

EFAZER os caminhos do retirante Severino, protagonista do auto de Natal "Morte e Vida Severina", de João Cabral de Melo Neto. Esse foi o objetivo de uma viagem ao sertão pernambucano em julho de 2000, para verificar, 45 anos depois de escrita a obra, como está aquela gente de vida difícil que virou poesia.

Há poucas referências dos locais de passagem de Severino. Seu ponto de partida, a serra da Costela, próximo ao território paraibano, é um local fictício, diz Eduardo Pazera, professor de geografia da Universidade Federal da Paraíba. Como início, tomamos então a nascente do rio Capibaribe, na serra do Jacarará, município de Poção - também nos limites com a Paraíba. O próprio João Cabral, no poema "O Rio", que conta a jornada do Capibaribe até sua foz, também começou a história naquele lugar. De lá, foi só seguir as cidades à margem do rio até Recife - a pé, no lombo de mototáxis ou de jipes-lotação.

Francisco é dono de um pedacinho de terra à beira da nascente do Capibaribe. $\mathrm{O}$ rio brota protegido por uma mata e vai escorrendo até formar uma lagoa, turva e espessa, tal qual a foz, em Recife. Graças ao olho-d'água que mantém a terra eternamente úmida, aquele lugar não conhece êxodo. Francisco está lá há 56 anos e nove filhos. "E meu pai já morava aqui há uns 80."

Parido, o rio começa a descer a serra do Jacarará, margeando pequenos sítios e casas de taipa. Por graça dos céus, este ano veio chuva. Chuva para plantar e fazer cultura. Nos últimos invernos, a região via apenas nuvens acumularem-se, sem soltar um pingo sequer de água. "Na época da seca, eu atendia mais de dez casos de crianças com diarréia por semana", lembra com certo alívio Ivonete Carneiro, agente de saúde do povoado de Sobrado. A ação desses profissionais, membros treinados da própria comunidade, está sendo fundamental para a diminuição da mortalidade infantil no Nordeste.

Para se ter uma idéia, em São José da Tapera, interior de Alagoas, considerado pela ONU o município mais pobre do Brasil, a taxa era de 147,94 mortes para cada mil nascidos em 1999 (Angola, há décadas em guerra civil, apresentava 170 para mil). Com a ação dos agentes de saúde, estimativas apontam queda da taxa de mortalidade em São José da Tapera para bem menos de 100. 
A mesma estimativa pode ser aplicada a todo o sertão e agreste: morrem menos crianças, mas ainda se morre de uma forma vergonhosa.

“- E se somos Severinos

iguais em tudo e na vida,

morremos de morte igual,

mesma morte severina:

que é a morte de que se morre

de velhice antes dos trinta,

de emboscada antes dos vinte,

de fome um pouco por dia"

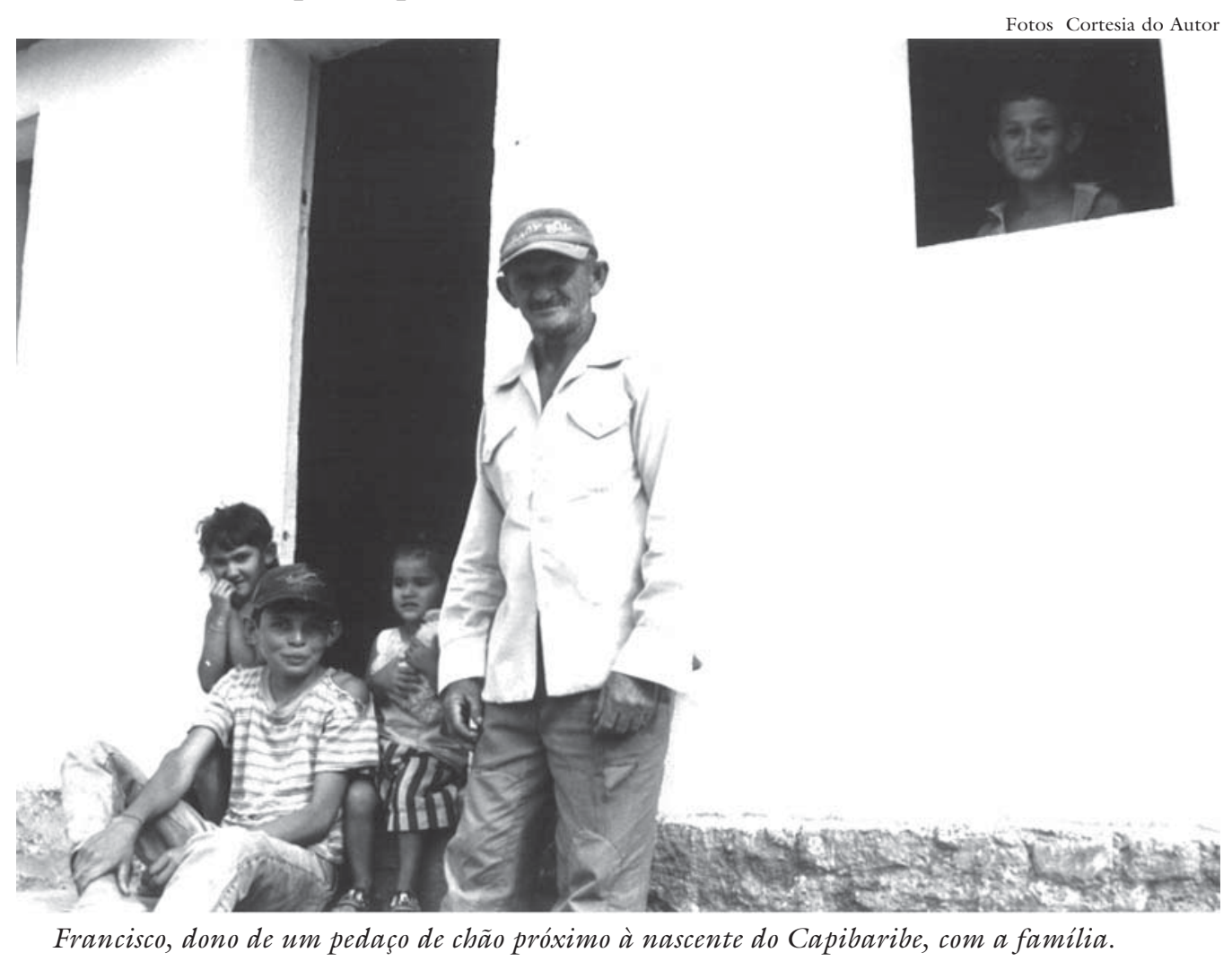

Segundo Ivonete, a multimistura - concentrado vitamínico que tem auxiliado em casos de desnutrição, fabricado com ingredientes encontrados no local - não chegou por lá, o que exige atenção redobrada. Pelo menos em Sobrado, as campanhas de vacinação e educação de mães têm surtido efeito. "Antes, quando chegava maio, as pessoas murmuravam: 'É mês de morrer criança'. Agora, maio é um mês igual aos outros”.

A tranqüilidade da agente de saúde foi trazida pela chuva. Naquela região, felicidade e tristeza são assuntos que têm muito mais a ver com a meteorologia do que com personalidade. 


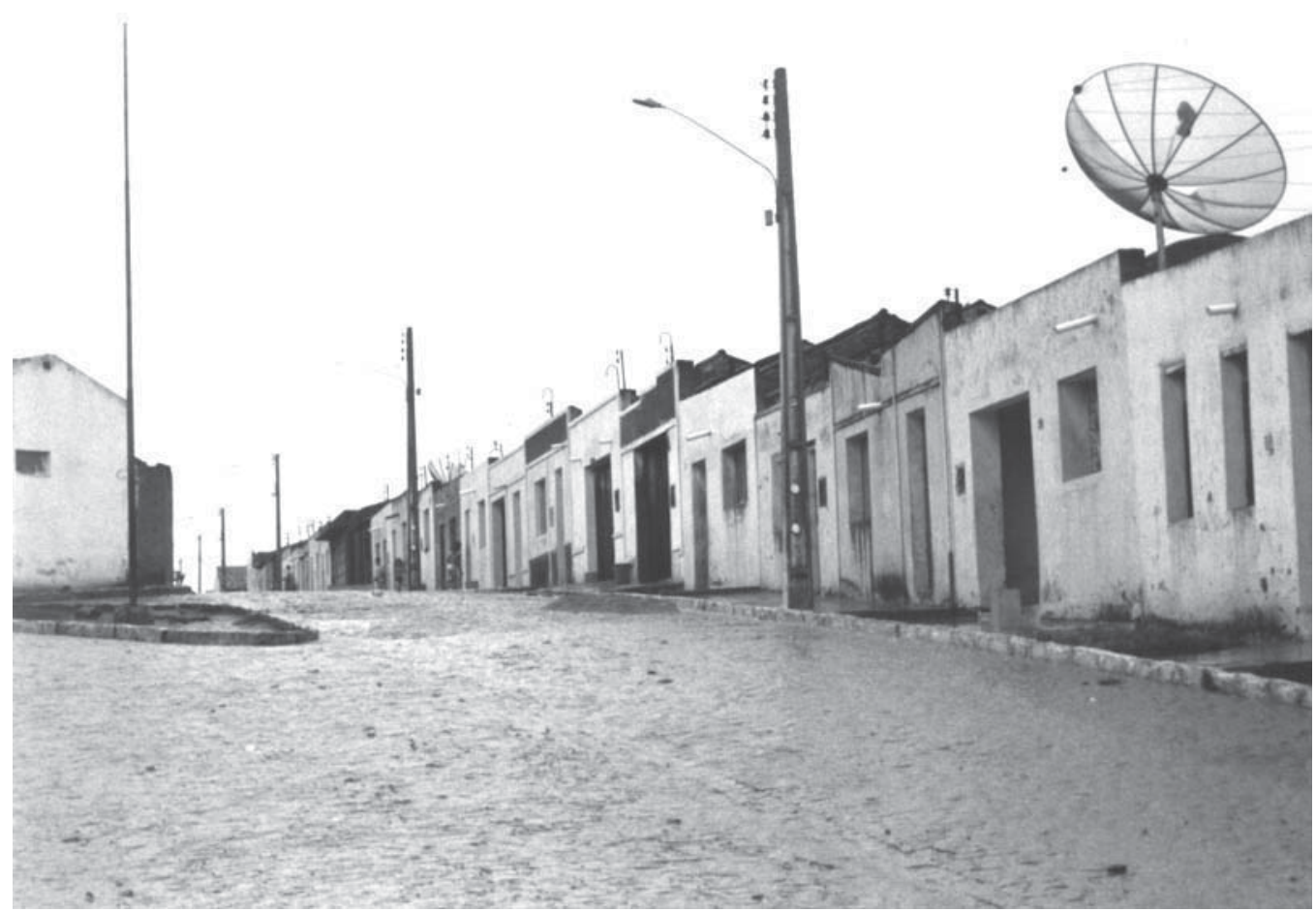

Povoado de Jacu, município de Jataúba.

Após um ziguezague interminável, com estradinhas de terra precárias e rochas nuas despontando do chão, atinge-se outro povoado, o de Jacu. A seca de 98 e 99 extinguiu o açude que abastecia a região. Os caminhões-pipa não davam conta da demanda. No lugar da água, uma fina camada de pó. Outro problema é o emprego. Muitos jovens abandonam suas casas e seguem rumo a São Paulo para tentar a sorte na construção civil, em fábricas, no comércio ambulante ou em qualquer ocupação que admita mão-de-obra não-especializada. Uns guardam algum dinheiro e voltam. Adaílto conseguiu até montar um negócio, uma pequena venda na rua principal. "Boa parte das pessoas fica aqui até o dinheiro acabar". Depois, o fluxo segue em direção ao sul novamente. Outros não conseguem voltar e ficam para sempre, muitos engrossando o contingente de favelados das grandes capitais.

Zacarias contraiu um empréstimo no Banco do Nordeste e não sabe como pagar. Ao contrário do personagem de João Cabral, este não é coronel, nem dono de nenhuma sesmaria, mas, sim, de um pequeno pedaço de chão e de umas três cabeças de gado que comprou com o dinheiro emprestado. Os juros são muito altos, e ele não sabe mais o que fazer. Opções até existem: devolver tudo e tocar para São Paulo, contrair outra dívida para pagar a primeira e rezar pela prosperidade (opção, aliás, preferida pela maioria dos pequenos produtores rurais brasileiros) ou simplesmente não fazer nada e esperar os credores tomarem tudo. Afinal de contas, o governo prefere doar cestas básicas (agora sem o leite) a estruturar melhores condições para o crédito agrícola. 
“- O meu nome é Severino, não tenho outro de pia.

Como há muitos Severinos, que é santo de romaria, deram então de me chamar Severino de Maria; como há muitos Severinos com mães chamadas Maria, fiquei sendo o da Maria do finado Zacarias".

E há os que ficam de fora até da esmola governamental e dependem de doações da iniciativa privada. Entre os municípios de Jataúba e Santa Cruz do Capibaribe há um aterro sanitário que serve a moscas, urubus e seres humanos de vários tamanhos e idades. Cláudio Emiliano é um deles.

Trabalhava no corte da cana-de-açúcar na cidade de Goiana, na Zona da Mata pernambucana. Tirava R\$ 100 por mês, mas só havia serviço para seis meses. Para sobreviver na outra metade do ano, começou a catar lixo reciclável no aterro da cidade. "Mas o prefeito expulsou todo mundo que fazia isso e mandou cercar o lixão”. Cláudio veio para Santa Cruz do Capibaribe e resolveu ficar de vez. Construiu uma casa no meio do aterro, com material abandonado no lixo. "Eu ficava mais doente lá do que aqui". Apesar do cheiro azedo e das moscas que rondam a comida exposta ao ar, ele consegue tirar mais que o dobro (R\$240) com a reciclagem do lixo do que com o corte da cana.

A agricultura deixou de ser o grande motor daquela região. Cidades como Santa Cruz do Capibaribe e Toritama aproveitaram a entrada de indústrias têxteis em Caruaru e viram proliferar fabriquetas, confecções e outros negócios ligados ao vestuário. Muitos moradores pegavam trabalho terceirizado de empresas maiores, como costurar calças e pregar zíperes e botões. Isso aconteceu há tempos. Hoje, o emprego que já atraiu ônibus de trabalhadores de outras regiões anda em baixa. A pequena Toritama, com quase 18 mil habitantes, vê a cada dia sua favela crescer. Retirantes de outros lugares que vislumbraram na cidade uma possibilidade de prosperar moram em casas de pau-a-pique. José Clementino da Silva ocupa uma delas, vive de bicos nas fábricas de roupas - quando aparecem -, mas diz que não arreda pé. Mesmo na última seca, quando tinha de pagar a atravessadores R\$ 50 por cada 400 litros de água. "Isso para lavar roupa e fazer comida. Para beber, a gente dava 50 centavos para cada lata de água." O dinheiro ganho no serviço literalmente se esvaía.

Toritama é a única cidade, citada nominalmente por João Cabral, que é passagem de Severino em sua caminhada para Recife. O retirante foi ajudar em um enterro de outro Severino, morto à bala por defender um pedaço de terra. 


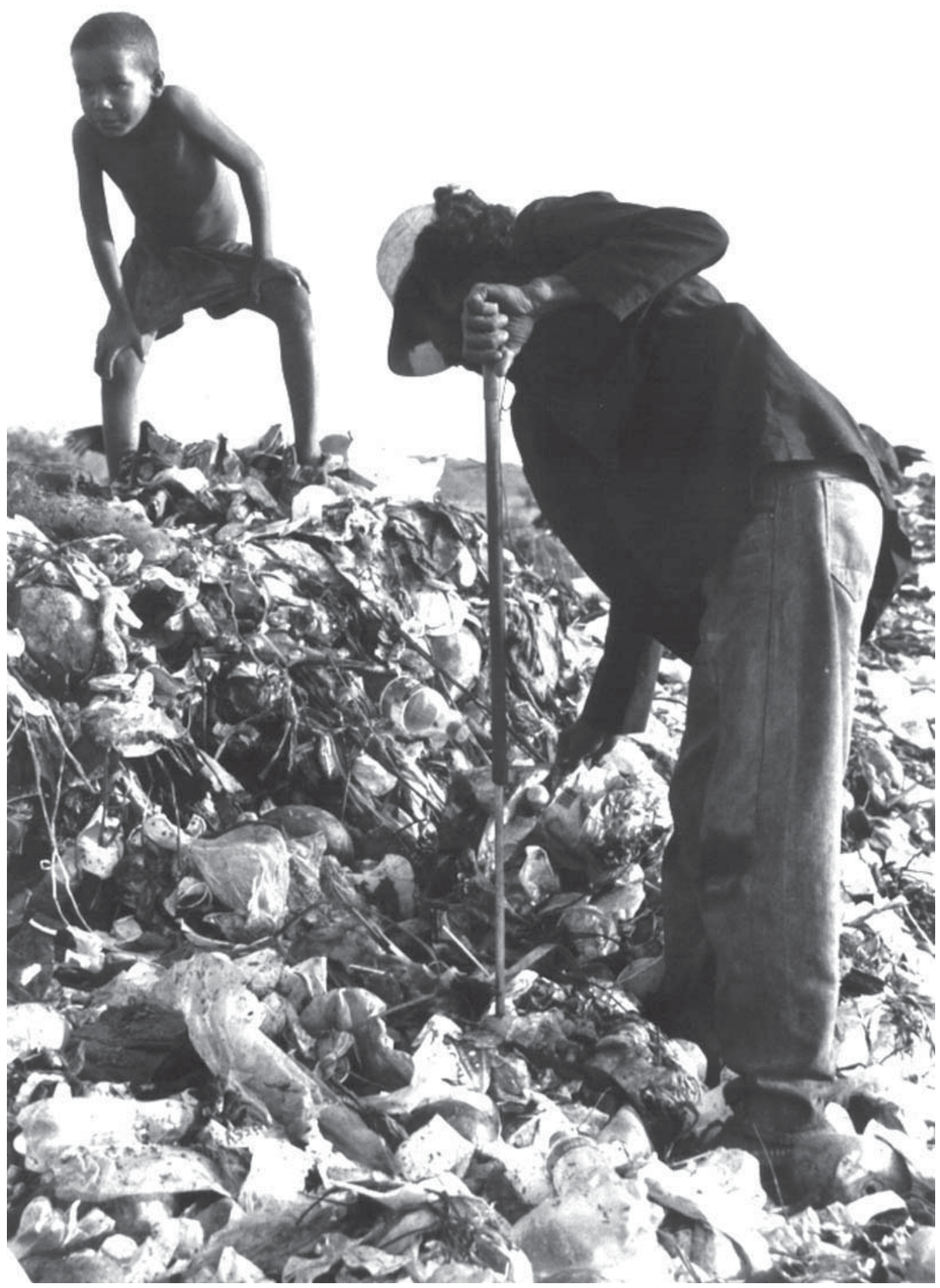

Cláudio Emiliano trabalha catando lixo reciclável no aterro de Santa Cruz do Capibaribe 


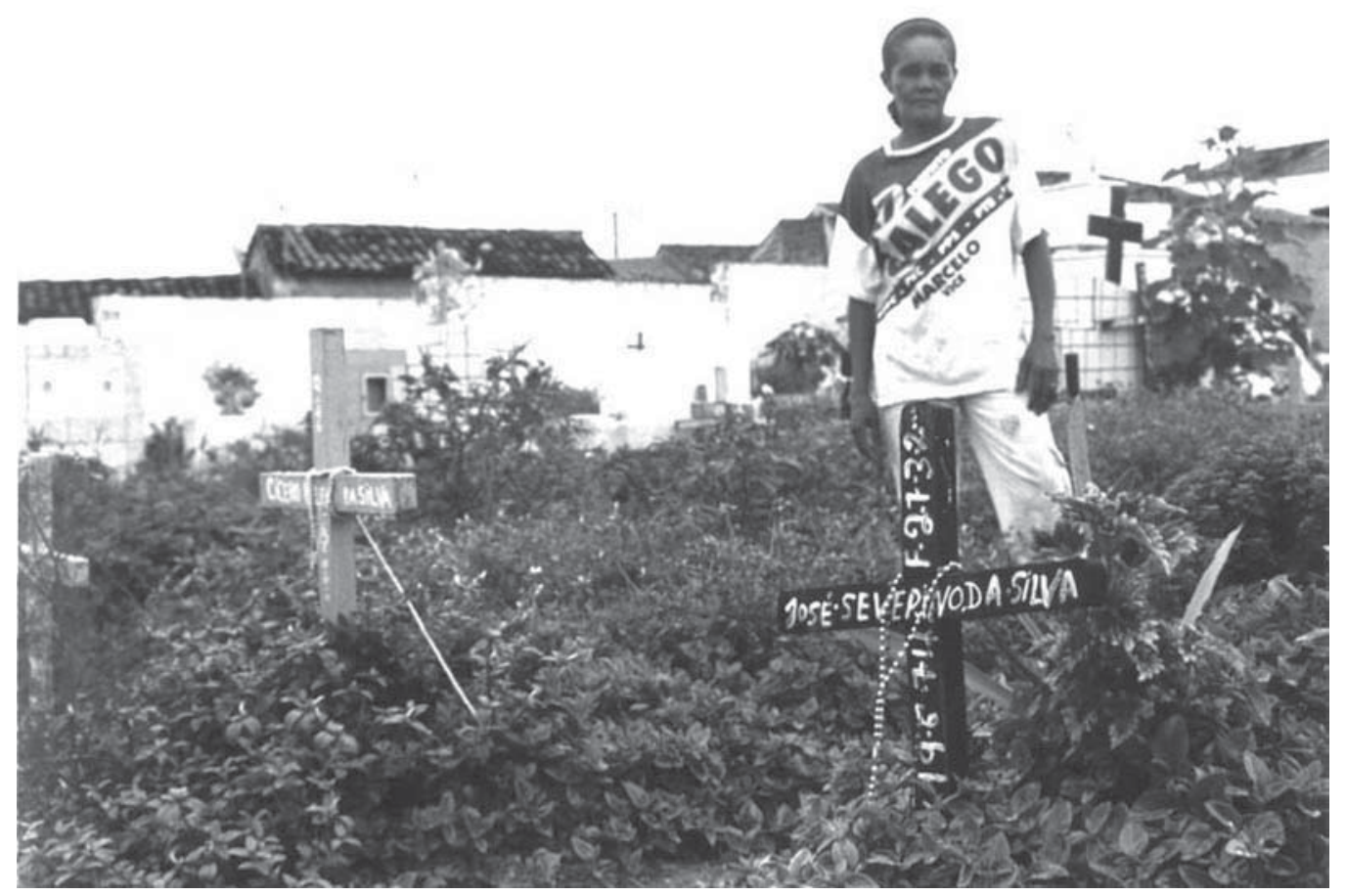

Maria da Silva, coveira do Cemitério de Toritama

“- E onde o levais a enterrar, irmãos das almas, com a semente do chumbo que tem guardada? - Ao cemitério de Torres, irmão das almas, que hoje se diz Toritama, de madrugada.

- E poderei ajudar, irmãos das almas? vou passar por Toritama, é minha estrada.

- Bem que poderá ajudar, irmão das almas, é irmão das almas quem ouve nossa chamada.

- E um de nós pode voltar, irmão das almas, pode voltar daqui mesmo para sua casa". 
Maria da Silva é coveira do cemitério de Toritama. Teve nove filhos, dos quais enterrou quatro. Ela é pau para toda obra, do enterro à exumação. "Morre-se muito de bala ainda hoje. É muito triste".

À beira da estrada que vai para Vertentes, estacas são presas ao chão e lonas estendidas. No dia 16 de julho, 800 famílias do Movimento dos Trabalhadores Rurais sem Terra (MST) ocuparam uma fazenda ali. Na verdade, um grande terreno baldio dominado pelo mato e onde não havia sinal de produção.

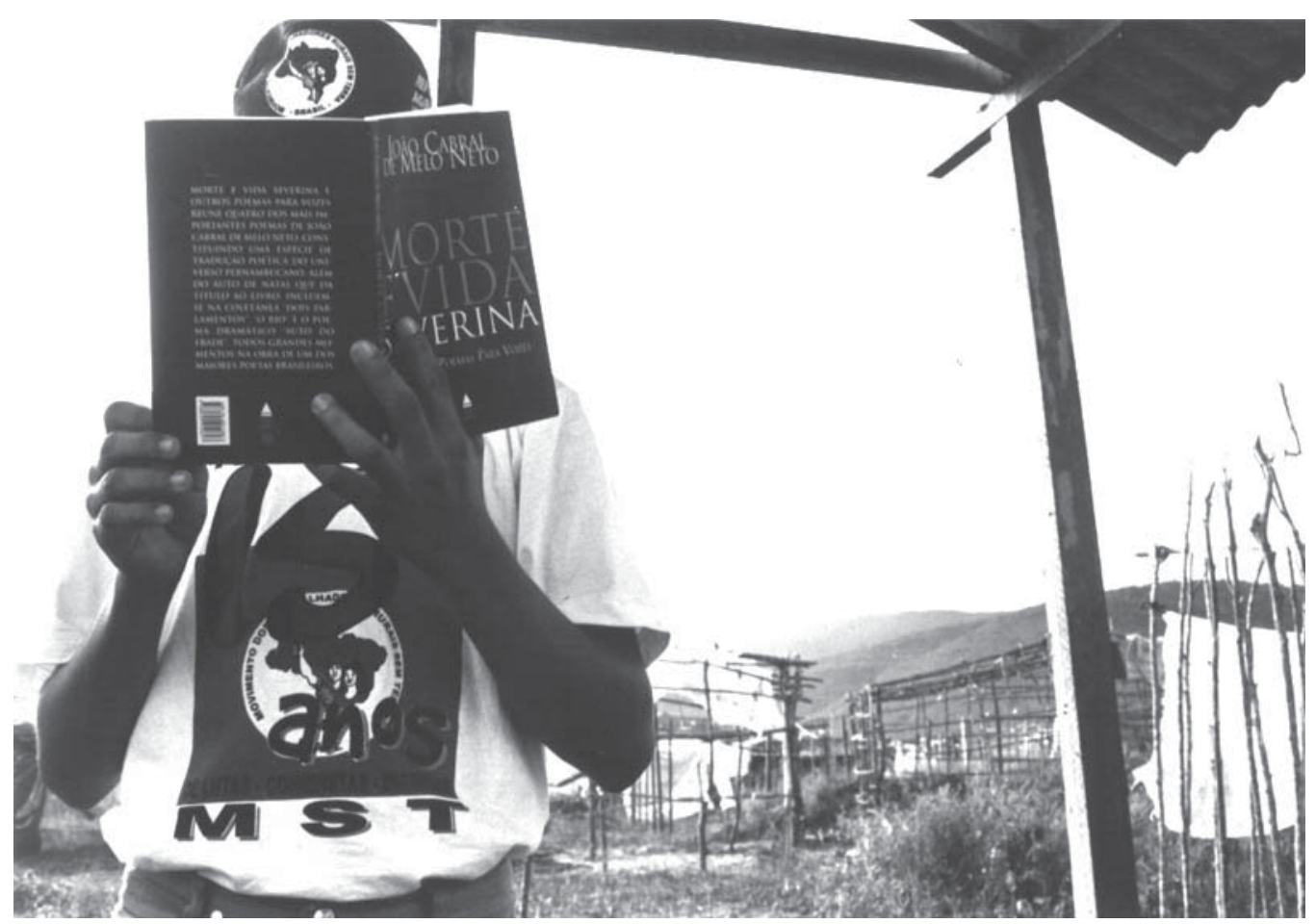

José Vereda, um dos secretários do MST no acampamento em Vertentes, lê Morte e Vida Severina

Muitos vieram parar no MST fugindo de trabalho forçado em granjas, criadouros de gado ou confecções no município de Caruaru. Um açude garante água para os acampados, que querem três fazendas desapropriadas, num total de 10 mil hectares. Os donos dessas terras seriam, de acordo com eles, latifundiários que possuiriam outras fazendas além dessas. De acordo com Marcelo dos Santos Silva, um dos coordenadores do acampamento, o Instituto Nacional de Colonização e Reforma Agrária (Incra) foi quem indicou a fazenda que poderia ser ocupada e desapropriada por não ter feito o recadastramento de propriedades rurais corretamente.

“O governo FHC quer assentar cinco mil famílias no agreste. Queremos que sejam pelo menos nove mil, e vamos lutar por isso", completa Marcelo. "Como estamos em ano eleitoral, acredito que dentro de cinco a seis meses a posse da terra seja transferida para nós e que montemos um assentamento". 
Em todo o Estado de Pernambuco, de Petrolina a Recife, há 96 acampamentos como aquele aguardando também a sua vez.

A idéia é plantar palma, algodão e um roçado de subsistência - se o tempo e o clima permitirem, é claro.

Essas pessoas não conheciam a história de Severino nem o poema de João Cabral, apesar de em toda a jornada não haver personagens tão fiéis à idéia da obra como lá. Em um dia de chuva repentina, reunidos em roda, contei a alguns a história do retirante que sai em busca do direito de lavrar, produzir e trabalhar. Eles perceberam a similaridade, apesar de quase meio século de separação. Com José Antônio Vereda, de apenas 17 anos, um dos secretários do movimento, nos detivemos no livro.

“- Pois fui sempre lavrador,

lavrador de terra má;

não há espécie de terra

que eu não possa cultivar...”

“Olha, emprego até tem. Mas eu lhe pergunto: a vida é só comer? Como se sente um pai que não pode dar um sapato para o filho descalço? Nenhum pai quer deixar o filho em dificuldades. Por que não podemos construir um futuro melhor para que nossos filhos produzam para eles mesmos?" Boa pergunta.

“- Essa cova em que estás,

com palmos medida,

é a conta menor

que tiraste em vida.

- É de bom tamanho,

nem largo nem fundo,

é a parte que te cabe

deste latifúndio.

- Não é cova grande,

é cova medida,

é a terra que querias

ver dividida".

Cortada pelo Capibaribe está Frei Miguelinho, a “capital dos garçons”. A cidade ganhou esse apelido devido ao fato de muitos bares e restaurantes de São Paulo e Recife empregarem pessoas de lá. O êxodo ali também é grande. Visitando os povoados do município, sente-se a falta de jovens andando pelas ruas. No vilarejo de Placa, só se avistam velhos e crianças. O prefeito Ivanildo de Oliveira informa, tristemente, que o fenômeno não ocorre só em Frei 
Miguelinho, mas em toda a região. Várias famílias colocaram as casas à venda, para ir embora com o dinheiro. A maioria, porém, não esperou, e é comum ver residências abandonadas, com inscrições de "Vende-se", em que o capim cresceu tanto que cobriu portas e janelas.

O rio é bem raso aqui. Dá até para um carro atravessar sem dificuldades. No verão, essa parte do Capibaribe fica intermitente, com pequenas lagoas que se alternam com grandes bancos de areia. Quando Severino fez sua jornada, pensou até em interrompê-la quando o rio também parou a sua. Uma obra no município de Surubim, porém, dezenas de quilômetros à frente, iria alterar o rumo das coisas.

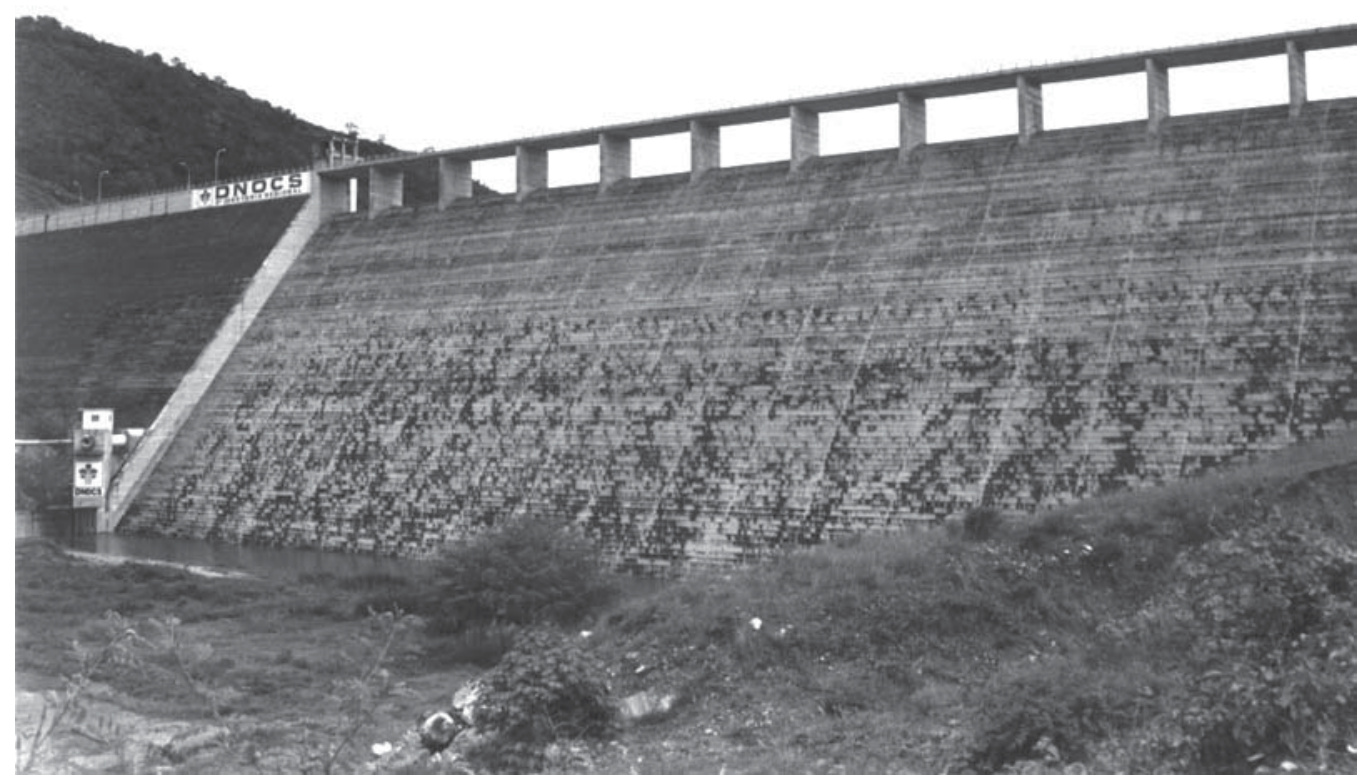

Barragem de Jucazinho, em Surubim

Finalizada em 1998, a barragem de Jucazinho - uma parede gigantesca de concreto, com $63 \mathrm{~m}$ de altura por quase $0,5 \mathrm{~km}$ de largura - está represando as águas do Capibaribe. O lago, depois de pronto, vai ter $25 \mathrm{~km}$ de extensão e 327 milhões de $\mathrm{m}^{3}$ de água. Com ele, surgirão ilhas no agreste, e jangadas e saveiros serão levados para o interior de Pernambuco. Cidades como Couro Dantas, Capivara e Trapiá já foram clonadas metros acima e seus habitantes transferidos antes que as águas tomassem conta de tudo. A lâmina d'água de Frei Miguelinho vai crescer até atingir uma altura equivalente à de um prédio de quatro andares. O lago deve chegar até a entrada do município de Toritama, ou seja, até ali, o Capibaribe permanecerá intermitente, e o sertão vai continuar conhecendo um rio de areia no verão. 
Adutoras estão sendo construídas para levar água às cidades da região, de Caruaru a Vertentes, já no ano que vem. "A idéia é perenizar o Capibaribe, que em certas épocas do ano deixa de correr devido à seca, pelo menos daquele ponto para baixo. Abastecer cidades e povoados, irrigar, instalar criadouros de peixe e camarão", explica Teomílson Cunha, um dos engenheiros da obra. Mas o lago pode secar? "Só se houver mais de cinco anos de seca brava". De acordo com estimativas do Departamento Nacional de Obras contra a Seca (Dnocs), responsável pela construção, serão beneficiados mais de 780 mil habitantes, a um custo de R\$ 61 milhões.

Pelo menos nesse pedaço o Capibaribe ganha ares de São Francisco. Talvez Antônio Conselheiro não estivesse errado em sua profecia.

“- Bem me diziam que a terra

se faz mais branda e macia

quanto mais do litoral/

a viagem se aproxima.

Agora afinal cheguei

nesta terra que diziam.

Como ela é uma terra doce

para os pés e para a vista.

Os rios que correm aqui

têm água vitalícia. (...)

Mas não avisto ninguém,

só folhas de cana fina;

somente ali à distância

aquele bueiro de usina

somente naquela várzea

um bangüê velho em ruína.

Por onde andará a gente

que tantas canas cultiva?

Feriando: que nesta terra

tão fácil, tão doce e rica,

não é preciso trabalhar

todas as horas do dia,

os dias todos do mês,

os meses todos da vida."

Desfiando o rosário de cidades abaixo, chega-se à Zona da Mata. Terras que já foram mar, mar verde, de tanta cana-de-açúcar plantada. Porém, de São Lourenço da Mata até além de Limoeiro, hoje amargam a decadência das usi- 
nas. Morros cobertos de capim à espera de plantação, que não vem pela falta de dinheiro, ao mesmo tempo em que não vão para a reforma agrária por pura especulação e mesquinharia.

Nos tempos de Severino, dezenas de chaminés de usina vomitavam fumaça dia e noite para dar conta da cana triturada nas moendas e queimada nos bueiros (fornalhas onde o bagaço é queimado para esquentar as caldeiras e mover o maquinário). Tradição histórica que vem da época dos engenhos, casas-grandes e senzalas nesta terra de Gilberto Freyre. Dizia-se que as usinas consumiam gente. Ruim com elas, pior sem elas. $\mathrm{O}$ fechamento de muitas deixou centenas de cortadores de cana sem ter o que fazer. Eles passam a tarde jogando dominó nas praças dos vilarejos, esperando aparecer alguma coisa. $\mathrm{Ou}$ seguem o rio até Recife para ser cobradores de ônibus, vendedores ambulantes ou exercer um sem-número de atividades sem carteira de trabalho assinada.

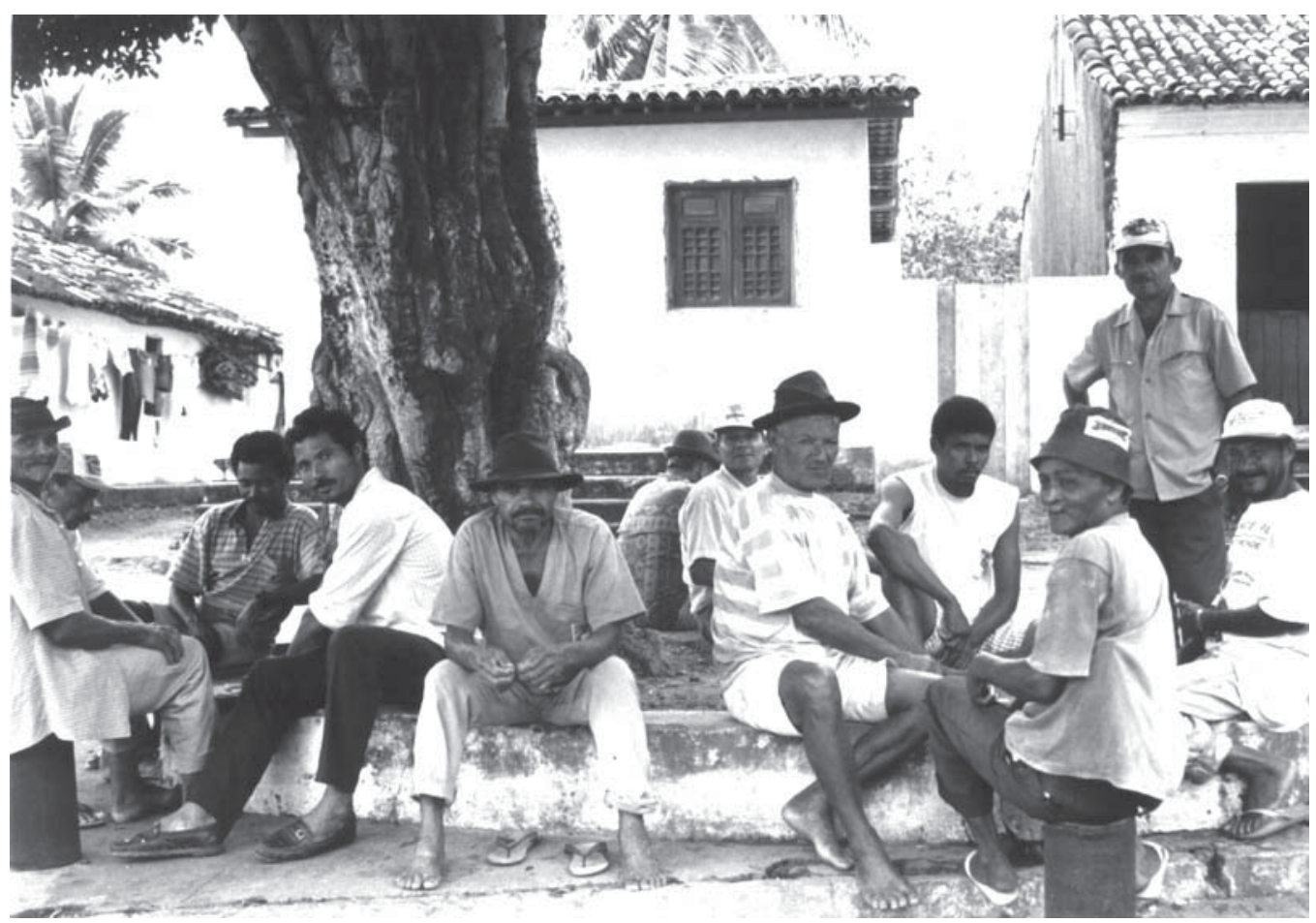

Cortadores de cana desempregados jogam dominó no povoado de Desterro

“As usinas estão fechando, falindo. E, para piorar, os cabras estão botando máquina pra tudo: é máquina pra colher, pra plantar, pra adubar. Gente não é mais necessária", reclama Nelson enquanto aguarda sua vez na mesa de dominó na vila de Desterro. No lugarejo há olarias, que não dão conta de empregar todo mundo. Muito menos as usinas Petribu e São José, na cidade de Carpina. Do mesmo proprietário, são as maiores ainda em funcionamento na região.

Às margens do Capibaribe, encontra-se o que já foi a usina Mussurepe, uma das maiores de Pernambuco, que empregava mais de 600 funcionários no 
seu apogeu e criou uma vila a seu redor que quase ganhou status de cidade. Resta hoje um esqueleto de metal, enferrujando com o tempo.

"Fechou por causa da má administração", lembra Genésio Ribeiro da Silva, ex-escriturário da usina. "A última moagem foi no dia 21 de dezembro de 1993, mas as dívidas com o INSS e os impostos atrasados e não pagos permanecem até hoje". Aos poucos, toda a parafernália de metal foi sendo desmontada e vendida.

"Parte da usina foi comprada por um pessoal de Araraquara, em São Paulo. Dizem que renasceu lá, está bonita. Pelo menos continua viva em algum lugar, né?" Outra parte foi para o Ceará e agora faz parte de uma fábrica de aguardente. A moenda está penhorada pelo Banco do Brasil.

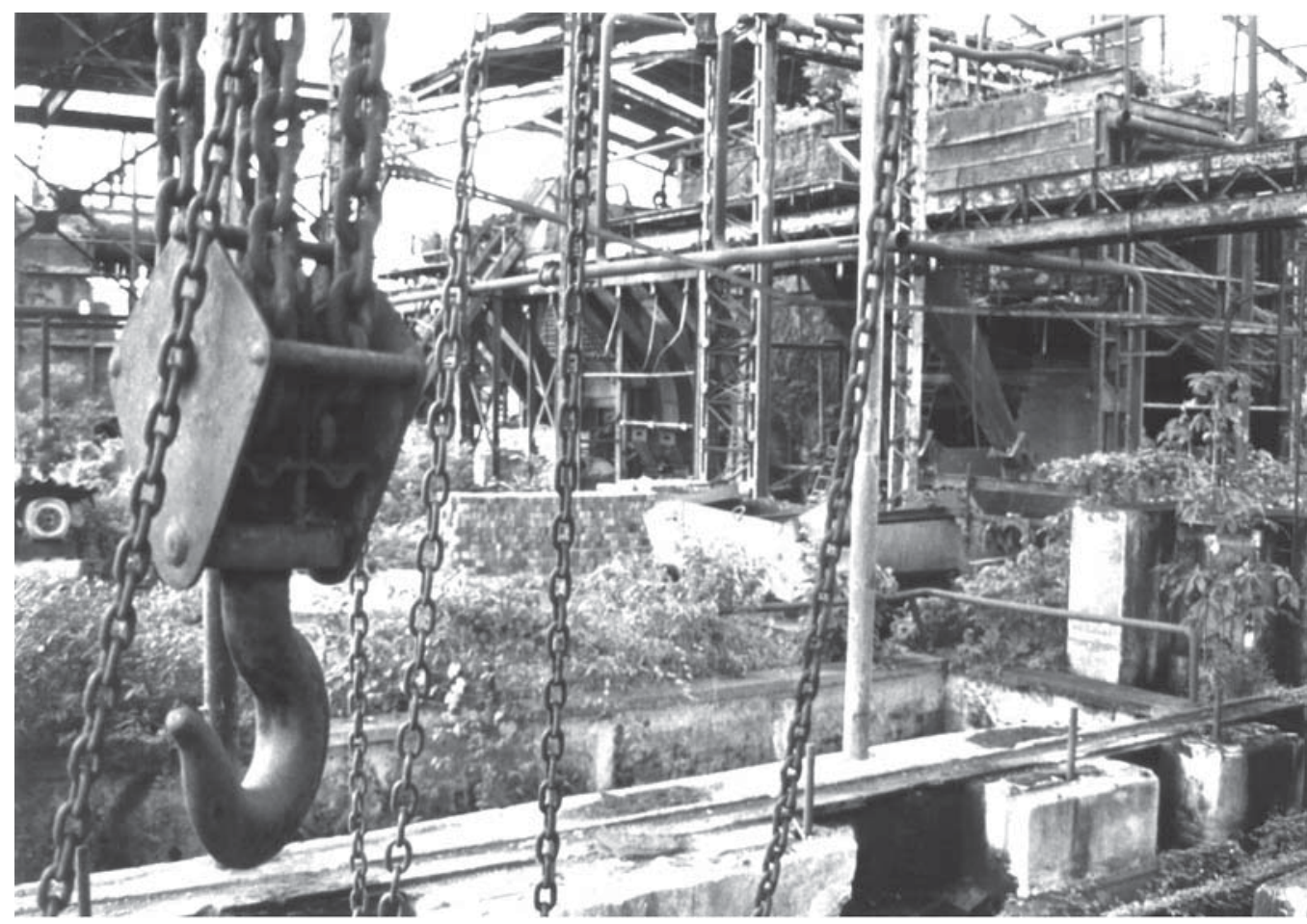

O que sobrou da Usina Mussurepe, às margens do Capibaribe, no município de Paudalbo

Reza a tradição da região que nenhum bueiro de usina pode ser demolido. Tem de cair sozinho para não trazer desgraça. Prova disso é que todas as usinas que faliram e tiveram suas dependências vendidas para a instalação de olarias ou outras indústrias mantiveram de pé essas construções de tijolos.

Segundo Genésio, na época da dissolução da Mussurepe, parte das terras foi para os trabalhadores da usina. "Mas o pessoal não teve orientação nem crédito para plantar e acabou perdendo tudo. Outros gastaram na farra e depois ficaram na miséria". Hoje, nomes de coronéis e de gente rica estão estampados nos certificados de propriedade. 
Na década de 80, quando a dívida com os bancos atingiu índices estratosféricos, "os trabalhadores chegaram a arrancar as tábuas da ponte sobre o Capibaribe para impedir que a usina fosse desmantelada e agüentasse um pouco mais", lembra Severino Soares de Lima Filho, de 31 anos. Seu pai trabalhou na Mussurepe desde 1918, sete anos após o engenho de cana do século XIX ter virado usina. Nascido em 1898, casou-se três vezes e teve 28 filhos - fora os perdidos pelo mundo. Hoje, Severino, o filho, trabalha com mototáxi na cidade de Paudalho.

“- Mas não senti diferença

entre o Agreste e a Caatinga,

e entre a Caatinga e aqui a Mata

a diferença é a mais mínima.

Está apenas em que a terra

é por aqui mais macia;

está apenas no pavio,

ou melhor, na lamparina:

pois é igual o querosene

que em toda parte ilumina,

e quer nesta terra gorda

quer na serra, de caliça,

a vida arde sempre com

a mesma chama mortiça".

O Capibaribe continua a descer até o litoral, onde corta Recife com seus meandros. A foz fica perto da cidade de Olinda, que ganhou da Unesco o título de patrimônio histórico da humanidade. Nas margens, muitos mangues e alguns catadores de caranguejos, em número menor que na década de 50 . O rio está mais sujo, seguindo a tradição das grandes metrópoles, que emporcalham seus cursos de água (com exceção do que acontece em países da Europa Ocidental, onde estão se corrigindo os erros do passado). Palafitas roubam a cena até onde a vista alcança, como favelas que acompanham o final do cortejo até o mar, lugar em que andar sobre as águas não é milagre. Milagre é sobreviver.

Muitos retirantes continuam a sair do interior em direção à capital. O Capibaribe não é mais o guia, e sim as estradas estaduais e federais construídas ao longo dos anos. Muitos não conseguem emprego e, para sobreviver, arranjam-se vendendo o que têm, vendendo a si mesmos.

Recife é uma das cidades brasileiras mais lembradas no exterior quando o assunto é turismo sexual. "Tem muito gringo que paga bem”, explica uma das prostitutas que fazem ponto na praia de Boa Viagem, um dos cartões-postais da cidade. A mercadoria nacional nunca esteve tão em alta lá fora. 


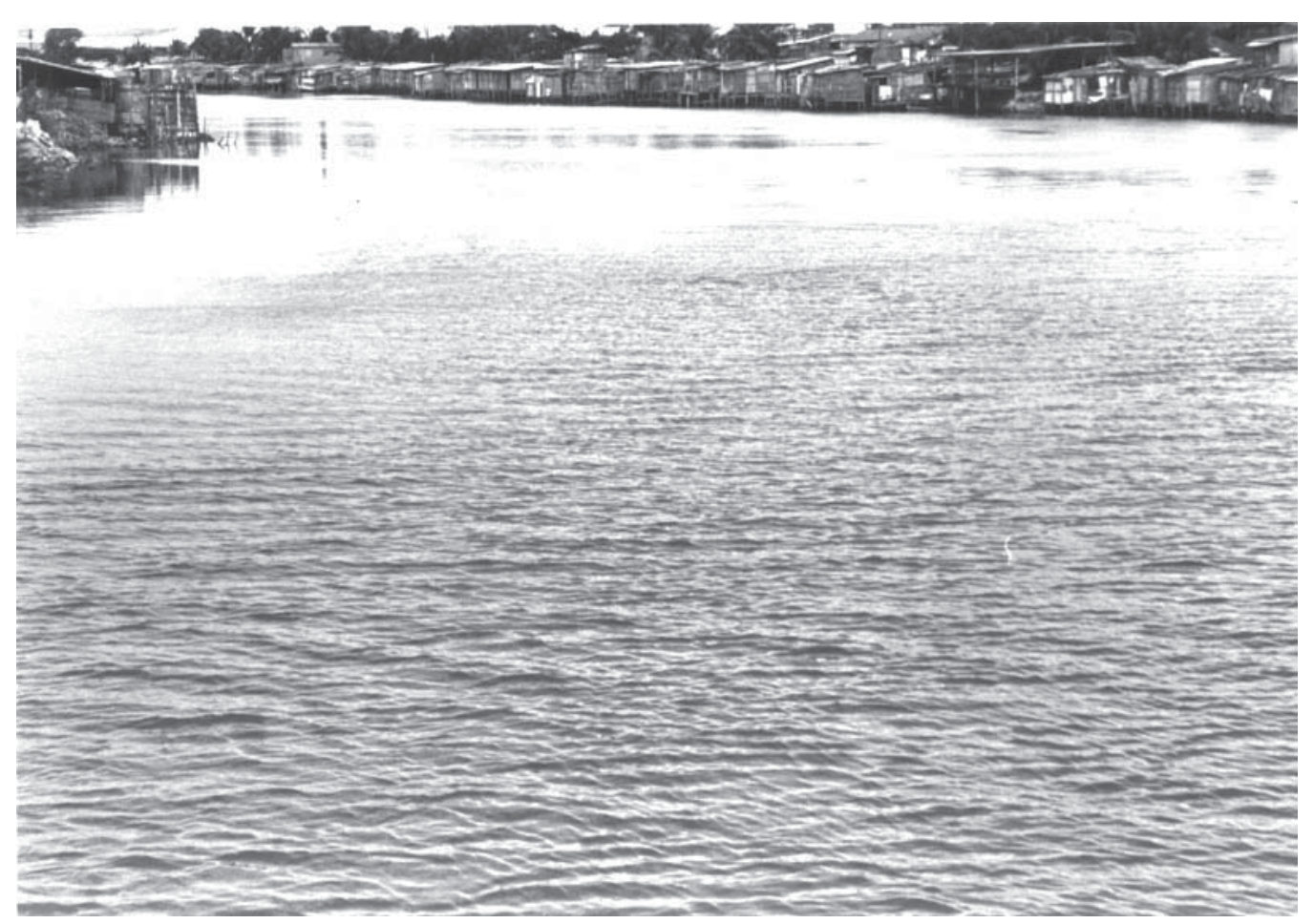

Favela de palafitas próxima à foz do Capibaribe, em Recife

Junto com as praias, os cemitérios são os locais mais democráticos de Recife. O de Santo Amaro, onde Severino ouviu dois coveiros reclamarem do número alto de enterros que tinham de fazer, continua o mais tradicional da cidade. Dá repouso a gente famosa, como Joaquim Nabuco, e a indigentes, que ostentam cruzes rústicas, repetindo em morte o que foram em vida. "Sete palmos? Não, não dá tempo, não dá espaço. Fazemos a seis, cinco. Já dá para enterrar assim." As histórias não mudaram muito entre os coveiros do Santo Amaro. "O pessoal que não pode pagar é assim: nós enterra e planta uma cruz. Só. Não é grande coisa, mas sai de graça. Tem dias que parece que a cidade inteira desce pra cá." Para poder ganhar mais um pouco, eles fazem bicos construindo lápides para o pessoal menos pobre.

Muitas coisas mudaram nos últimos 45 anos nas terras atravessadas pelo rio Capibaribe, interior de Pernambuco. Outras, nem tanto. O sertão ganhou antenas parabólicas para captar os dramas de Hollywood nas noites de sábado - mas o encanamento para a água continua distante. Recebeu fábricas para produzir calças que vão de avião para o Rio de Janeiro, São Paulo e Porto Alegre - enquanto as pernas continuam indo de ônibus ou pau-de-arara mesmo. Cidades do interior reciclam lixo - e o usam como casa, roupa e comida. As usinas de canade-açúcar, consumidoras de gente, finalmente fecharam - e deixaram sem emprego milhares de mãos calejadas. Os latifúndios daquela época não existem mais - uns mudaram de dono, cresceram e se multiplicaram. Catadores de caranguejo são mais raros na foz do Capibaribe - a poluição do rio os levou para outros mangues. 
Muita coisa mudou nos últimos 45 anos nas terras atravessadas pelo rio Capibaribe. Mudou para poder continuar praticamente a mesma coisa. Mas, apesar de tudo isso, o povo mantém sua fé. Acredita que a vida pode ser melhor. $\mathrm{O}$ próprio fato de ainda haver retirantes é prova disso, caminhantes que saem em busca de algo - mesmo que não façam idéia de onde a estrada vai terminar.

Muitos acreditam que a barragem de Jucazinho é a maior esperança para a região cortada pelo Capibaribe, mas existe outra, esta perene, sem risco de secar com o verão. Os sem-terra acampados em Vertentes, contando apenas com algumas panelas, uma ou duas mudas de roupa e um pedaço de lona, mostram a diferença entre 1955 e hoje. O povo do sertão e do agreste agora está decidido a ficar e a lutar pelo que acredita certo, como o seu direito à terra e a uma vida melhor. Vida que vale a pena, mesmo sendo severina.

“- Severino retirante, deixe agora que lhe diga:

eu não sei bem a resposta da pergunta que fazia, se não vale mais saltar fora da ponte e da vida; nem conheço essa resposta, se quer mesmo que lhe diga é difícil defender, só com palavras, a vida, ainda mais quando ela é esta que vê, severina; mas se responder não pude à pergunta que fazia, ela, a vida, a respondeu com sua presença viva.
E não há melhor resposta que o espetáculo da vida: vê-la desfiar seu fio, que também se chama vida, ver a fábrica que ela mesma, teimosamente, se fabrica, vê-la brotar como há pouco em nova vida explodida; mesmo quando é assim pequena a explosão, como a ocorrida; mesmo quando é uma explosão como a de há pouco, franzina; mesmo quando é a explosão de uma vida severina."

Leonardo Sakamoto é jornalista formado pela ECA-USP e mestrando em Ciência Política pela FFLCH-USP. A viagem foi realizada em julho de 2000 e o artigo originalmente publicado pela revista Problemas Brasileiros. 